Egyptian Journal of Rabbit Science, 27 (2): 507- 521(2017)

\title{
GENETIC ASPECTS OF POST-WEANING FOR GROWTH TRAITS IN NEW ZEALAND WHITE RABBITS.
}

\author{
Amira S. El-Deighadi* and M. K. Ibrahim** \\ *Animal Production Research Institute, Agriculture Research Center, \\ Ministry of Agriculture, Dokki, Cairo, Egypt. \\ **Department of Animal Production, Faculty of Agriculture, Banha \\ University, Moshtohor, Egypt.
}

This study was carried out to estimate the genetic parameters for post-weaning body weight at 4, 6, 8, 10 and 12 weeks and growth rate during the periods 4-6, 6-8, 8-10 and 10-12 weeks in New Zealand White (NZW) rabbits. Data consisted of records of 3891 progenies born from 219 does and 65 sires during five consecutive years. The statistical analysis was carried out by weighted data using a single trait animal model to estimate additive, common litter effects and residual variances. The model included the fixed effects (season, parity and litter size at birth) and random effects (additive genetic and common litter effect in addition to random error) for post-weaning growth traits.

Estimates of $\mathrm{CV} \%$ of body weights decreased with the advancement of age. CV\% estimates for growth rate during periods were not consistent and slightly high. Estimates of heritability for body weights ranged between low and moderate, from 0.13 to 0.20 at 4, 6, 8, 10 and 12 weeks of age, respectively. Estimates of heritability were low and not consistent growth rate during the name periods and ranged from 0.06 to 0.13. Common litter effect $\left(c^{2}\right)$ of body weight at weaning was higher (0.69) compared to that at later age. It declined gradually with the advancement of age (0.54, 0.44, 0.37 and 0.32 at 6, 8, 10 and 12 weeks of age). Common litter effects $\left(c^{2}\right)$ of growth rate between weaning weight and 6 weeks were higher than all the other periods. Estimates of error proportions $e^{2}$ for body weight ranged from 0.18 to 0.48 , and were moderate or slightly high for growth rate during all periods. Estimates of minimum and maximum, all progeny, breeding values $(B V)$ for body weight ranged from -0.244 to 0.389 , from -0.245 to 0.362 , from -0.259 to 0.346 , from -0.195 to 0.235 and from -0.233 to 0.265 grams at 4, 6, 8, 10 and 12 weeks of age, respectively. 
Breeding values decreased with advancement of age (0.633, 0.607, 0.605, 0.403 and 0.498 grams) at 4, 6, 8, 10 and 12 weeks of age, respectively. Also, their accuracies were high. Minimum, maximum and range of predicted breeding values of growth rate were high during 4 to 6 weeks the period and decreased at 6 to 8,8 to 10 and 10 to 12 weeks and their accuracies were high for all periods. Pearson and rank correlation were estimated among breeding values by STDFREML, all possible Pearson and rank correlation between body weight at different ages were low or moderate or high, positive and significant $(0.03,0.16$ and 0.28), while the correlation were negative, low and not significant between body weight, at 4 and 6 weeks, between 6 and 8 weeks and between 10 and 12 weeks (-0.10,-.0.001and -0.004). Estimates of Pearson and rank correlation, between most growth rate during all the periods varied widely, low, moderate or high positive and significant (0.05, 0.14 and 0.34), while the correlation were negative, low and non significant during the period from 4 to 6 weeks (-0.004).

Conclusively, the estimates of heritabilities were moderate for body weight; selection at these ages may be a useful method for improving rabbit growth. The common litter effect is very important for post-weaning growth traits; one can conclude that the common litter effect should be included in the genetic evaluation of breeding programs. The correlation estimates are obviously age dependent and reveal that correlated response of selection is quite feasible.

Keywords: Common litter effect, heritability, breeding value, Pearson and rank correlation.

Rabbit play an important role in solving problem of meat shortage. Rabbits compared to other livestock species require low investments at the same time they are highly prolific. This is due to high potential for reproduction, rapid growth rate, and reaches sexual maturity at an early age, and efficient feed conversion. In addition, the rabbit meat is white, easily digestible, and low in cholesterol and sodium content. Also, they have short generation interval, limited vital space and ease of rearing. It is evident that the body weight and growth rate of weaned rabbits depend on various factors such as, age and weight of dam at kindling, litter size at birth, season of kindling, sex of kits etc (McReynolds, 1974; Bhasin et al., 1996). Reliable estimates of genetic parameters are needed for accurate prediction of breeding 
values and for the design of efficient improvement programmers'. Estimation of genetic parameters involves partitioning phenotypic covariances between relatives into two or more components such as additive genetic effects, dominance, epistasis and permanent and temporary environmental effects (Falconer, 1981). Estimates of heritabilities and common environmental effects are functions of variance components, and these parameters may be specific for a particular population and time period. Heritability is a concept that summarizes how much of the variation in a trait is due to variation in genetic factors. It is an essential determinant of genetic progress. Knowledge of heritability estimate is therefore an important guide to the best route for genetic improvement (Lasley, 1978).

Therefore, the aim of this study to estimate genetic aspects of postweaning for growth traits in New Zealand White rabbits.

\section{MATERIALS AND METHODS}

\section{Animals and data}

Individual body weight (BW) at 4, 6, 8,10 and 12 weeks and growth rate $(\mathrm{RG})$ during the periods $4-6,6-8,8-10,10-12$ and 4-12, 6-12 and 8-12 weeks in New Zealand White (NZW) rabbits were recorded. Data consisted of records of 3891 progenies born from 219 does and 65 sires for five consecutive years. Mating, according to the breeding plan, a buck was assigned at random for every 3-4 does for mating with a restriction of avoiding full sib, half sib and parent-offspring mating. Each buck was given the chance to produce all his litters from the same females all over the period of the study. Does were palpated 10 days later. Therefore, the mating design produced several progeny for each successful sire-dam combination.

Starting mixed model was obtained applying REML method of VARCOMP procedure of SAS 2003. These starting values used for the estimation of the more precise and reliable estimates of single-trait animal model variance and covariance components

Data were analyzed using single-trait animal model of body weight and growth rates using MTDFREML programs of Boldman et al. (1995). Analyses were done according to such general model:

$$
\mathrm{y}=\mathrm{Xb}+\mathrm{Z}_{\mathrm{aa}}+\mathrm{Z}_{\mathrm{cc}}+\mathrm{e} . \quad(\text { Model2) }
$$

Where, $y=$ Vector of observation, $X=$ Incidence matrix of fixed effects; $b=$ vector of fixed effects including season (3 levels), parity (5 levels), and type 
of birth (7 levels); $\mathrm{Z}_{\mathrm{a}}$ and $\mathrm{Z}_{\mathrm{c}}=$ Incidence matrices corresponding to random effects of additive (a) and common litter, $\mathrm{e}=$ Vector of random errors.

All estimates of BLUP were derived by single-trait animal model (STAM) using the STDFREML program (Boldman et al. 1995) adapted to use the sparse matrix package, SPARSPAK (George and Ng 1984). The STAM considered the relationship coefficient matrix $\left(\mathrm{A}^{-1}\right)$ among animals in the estimation (Boldman et al. 1995). Heritability were computed as additive direct $\left(h^{2} a=\sigma^{2} a / \sigma^{2} p\right)$, where $\sigma^{2} a$ and $\sigma^{2} p$ are the variances due to effects of additive genetic and phenotypic, respectively.

$$
\text { Growth rate }=\frac{W 2-w 1}{1 / 2(w 1+W 2)} \times 100
$$

Where $\mathrm{W} 1=$ Weight at the beginning of the period, $\mathrm{W} 2=$ Weight at the end of the period.

\section{Breeding values:}

The (co) variances matrix estimated using STDFREML analysis was used by the same software to predict breeding values, their accuracies (raâ) and standard errors. The accuracies of BLUP estimate for each individual was estimated according to the equation suggested by Henderson (1973).

\section{RESULTS AND DISCUSSION}

Means, standard deviations, coefficients of variation (CV\%), minimum and maximum for body weights at 4, 6, 8, 10 and 12 weeks of age $(\mathrm{kg})$ and growth rate during the period of 4-6, 6-8, 8-10 and 10-12 weeks of age (\%) are presented in Table 1.

Means of body weights and growth rates observed at different ages were within the range reported (Khalil and Afifi, 2000; Afifi and Farid, 2001; Iraqi 2003 \& 2008; Youssef, 2004; Abou Khadiga, 2004; Youssef et al., 2008; Youssef et al., 2009; Nowier, 2012 and El-Badawy, 2015). Means of growth rate between weaning weight at 4 weeks and 6 weeks were higher than during all other period. This might be due to maternal ability along with their postnatal milk production. Estimates of $\mathrm{CV} \%$ of body weights decreased with the advancement of age. This trend might be reflecting that when the bunnies advance in age, they become progressively less sensitive to non-genetic maternal effects (Khalil et al., 1987). CV\% estimates for growth rate during all periods were not consistent and slightly high. This means that improvement of these traits through phenotypic selection may be easier to achievement. 
Table 1. Means, standard deviations, coefficients of variation (CV\%), minimum and maximum for body weights at 4, 6, 8, 10 and 12 weeks of age $(\mathrm{kg})$ and growth rate during the period of 4-6, 6-8, 810 and $10-12$ weeks of age (\%) in NZW rabbits.

\begin{tabular}{|lcccccc|}
\hline Traits & No & Mean & SD & CV\% & Min & Max \\
\hline Body weights: & & & & & & \\
BW4 & 3891 & 0.598 & 0.19 & 32.66 & 0.100 & 1.000 \\
BW6 & 3777 & 0.921 & 0.24 & 25.80 & 0.300 & 1.800 \\
BW8 & 3575 & 1.241 & 0.26 & 20.69 & 0.500 & 2.300 \\
BW10 & 2754 & 1.572 & 0.26 & 16.89 & 0.800 & 2.500 \\
BW12 & 2731 & 1.893 & 0.27 & 14.49 & 1.000 & 3.000 \\
& & & & & & \\
Growth rate: & & & & & & \\
RG4-6 & 3771 & 43.62 & 18.41 & 42.20 & 9.52 & 125.00 \\
RG6-8 & 3561 & 29.47 & 12.05 & 40.90 & 5.41 & 100.00 \\
RG8-10 & 2721 & 23.32 & 10.15 & 43.55 & 4.88 & 94.74 \\
RG10-12 & 2722 & 19.06 & 9.21 & 48.32 & 3.92 & 200.00 \\
& & & & & & \\
\hline
\end{tabular}

\section{Variance components and proportions:}

Proportions and standard error of additive genetic $\left(\mathrm{h}^{2}{ }_{\mathrm{a}}\right)$, common litter effect $\left(\mathrm{c}^{2}\right)$ and error $\left(\mathrm{e}^{2}\right)$ relative to phenotypic variance for body weights at $4,6,8,10$ and 12 weeks of age $(\mathrm{kg})$ and growth rate during the periods of 4$6,6-8,8-10$ and $10-12$ weeks of age $(\%)$ in NZW rabbits are presented in Table 2.

\section{Heritability:}

Estimates of heritability in Table 2 for body weights were low and moderate, ranged from 0.13 to 0.20 at $4,6,8,10$ and 12 weeks of age. Estimates of heritability were low and not consistent for growth rate during the studied periods and they ranged from 0.06 to 0.13 . Moderate heritabilities, obtained in this study, for body weights were similar to those estimates reported earlier (Estany et al., 1992; Ferraz and Eler 1994 and 1996 Gomez et al., 2000; Khalil et al., 2000; Iraqi et al., 2002 and Iraqi, 2008; Behiry, Fatmah 2014). Iraqi (2003) and Youssef et al. (2009) with BR and/or NZW rabbits found increasing $\mathrm{h}^{2}{ }_{\mathrm{a}}$, with the advancement of age, may be due to high non-additive genetic effects such as common litter effects. While, heritability obtained in this study, for body weight was 
Table 2. Proportions and standard error of additive genetic $\left(\mathrm{h}_{\mathrm{a}}^{2}\right)$, common litter effect $\left(\mathrm{c}^{2}\right)$ and error $\left(\mathrm{e}^{2}\right)$ relative to phenotypic variance for body weights at $4,6,8,10$ and 12 weeks of age and growth rate during the period of $4-6,6-8,8-10$ and $10-12$ weeks of age in NZW rabbits.

\begin{tabular}{|lccl|}
\hline \multicolumn{1}{|c}{ Traits } & $\mathbf{h}^{2}{ }_{\mathrm{a}} \pm \mathbf{S E}$ & $\mathbf{c}^{2} \pm \mathbf{S E}$ & $\mathbf{e}^{2} \pm \mathbf{S E}$ \\
\hline Body weight: & & & \\
BW4 & $0.13 \pm 0.03$ & $0.69 \pm 0.02$ & $0.18 \pm 0.02$ \\
BW6 & $0.15 \pm 0.03$ & $0.54 \pm 0.02$ & $0.31 \pm 0.02$ \\
BW8 & $0.19 \pm 0.04$ & $0.44 \pm 0.02$ & $0.38 \pm 0.03$ \\
BW10 & $0.18 \pm 0.04$ & $0.37 \pm 0.03$ & $0.45 \pm 0.03$ \\
BW12 & $0.20 \pm 0.05$ & $0.32 \pm 0.03$ & $0.48 \pm 0.04$ \\
Growth rate: & & & \\
RG4-6 & $0.18 \pm 0.05$ & $0.39 \pm 0.02$ & $0.43 \pm 0.04$ \\
RG6-8 & $0.10 \pm 0.04$ & $0.26 \pm 0.02$ & $0.64 \pm 0.03$ \\
RG8-10 & $0.13 \pm 0.04$ & $0.15 \pm 0.02$ & $0.72 \pm 0.02$ \\
RG10-12 & $0.06 \pm 0.03$ & $0.15 \pm 0.02$ & $0.79 \pm 0.03$ \\
\hline
\end{tabular}

higher than results of $0.007,0.043$ and 0.082 for BW4, BW8 and BW11 weeks of age, respectively. Ferraz et al. (1992) and, Lukefahr et al. (1996), who reported heritability of 0.04 for weaning weight based on animal model estimates. The differences observed in the heritability estimate might be due to differences in the method of estimation and the role played by various environmental factors. Moderate heritabilities obtained here for body weights might indicate that suggested that improvement of body weight could possibly be achieved through selection.

\section{Common litter effect $\left(c^{2}\right)$ :}

Common litter effect $\left(c^{2}\right)$ of body weight at weaning was higher (0.69) compared to that at advanced age. It declined gradually when bunnies older $(0.54,0.44,0.37$ and 0.32 at $6,8,10$ and 12 weeks of age). Table 2, indicated that bunnies started to express than own genetic abilities along with increasing its variances and also declining maternal effects. The same trend was observed by Ferraz et al., 1992; Ferraz et al., 1996; Iraqi et al., 2002; Iraqi 2003; Hassan 2004; Youssef, 2004; Iraqi 2008 and Youssef et al., 2008 $\&$ 2009). Also, common litter effects $\left(c^{2}\right)$ of growth rate between weaning weight and 6 weeks were higher than rest of all the periods. Lukefahr et al. (1996) reported that common environmental variances for weaning weight 
and mature weight were considerably larger than those of additive genetic variance or residual environmental variance. Also, Ferraz et al. (1992), Iraqi et al. (2002), Iraqi (2003) and Iraqi (2008) reported that common litter influences might be more important than additive genetic effects for postweaning growth in rabbits. This trend could be to some extent to the consequence of the genetic variation, in some characters of the dam, such as mothering or maternal ability (Mrode, 1996), Youssef et al., (2009) reported that the common litter effect could be accounted for common maternal environmental variation, non-additive genetic variation and any sire $\mathrm{x}$ dam interaction that may present, since this component largely represented covariance between full sibs families. In addition to that, another source of common maternal environmental variance between families may be due to nutritional and/or climatic factors. From these results, the common litter effect should be considered in genetic evaluation of breeding programs. Behiry, Fatmah (2014) reported that NZW rabbits are affected more by common litter effect, than Baladi Red and crossbred rabbits.

\section{Error proportion $e^{2}$ :}

Error proportions $\left(\mathbf{e}^{\mathbf{2}}\right)$ estimated by using the relationship between animals and the inclusion of common litter effect $\left(\mathbf{c}^{2}\right)$ in the animal in the model lead to reductions in error proportions. The estimates of $\left(\mathbf{e}^{2}\right)$ for body weight that ranged from 0.18 to 0.48 . However, they were moderate or slightly high to growth rate during all the periods (Table 2). Results of the current study here were similar to those estimates by Youssef, 2004 and Youssef et al., 2009. Iraqi (2003) showed that estimates of experimental error variance were very high when using Model 1, with direct additive + error for all the studied body weights. However, he related that these variances were reduced when using Models 2, with direct additive + common litter effect + error. Therefore, common litter and maternal genetic effects should be considered in the model (Ferraz et al., 1992).

\section{Breeding value:}

Estimates of minimum and maximum of all progeny breeding values (BV) for body weight ranged from -0.244 to 0.389 , from -0.245 to 0.362 , from -0.259 to 0.346 , from -0.195 to 0.235 and from -0.233 to 0.265 grams at $4,6,8,10$ and 12 weeks of age respectively. Ranges of breeding values decreased with advanced of age $(0.633,0.607,0.605,0.403$ and 0.498 grams) at 4, 6, 8, 10 and 12 weeks of age respectively. Also, their accuracies were high (Table3). 
Table 3. Breeding values (BV), standard error (SE) and accuracy ranges (RI) of body weights at 4, 6, 8, 10 and 12 weeks of age $(\mathrm{kg})$ and of growth rate during the period of 4-6, 6-8, 8-10 and 10-12 weeks of age $(\%)$ in NZW rabbits.

\begin{tabular}{|c|c|c|c|c|c|c|c|c|c|c|}
\hline \multirow[t]{2}{*}{ Traits } & \multicolumn{4}{|c|}{ Min } & \multicolumn{3}{|c|}{ Max } & \multicolumn{3}{|c|}{ Range } \\
\hline & BV & SE & $\mathbf{R}$ & & BV & SE & RI & BV & SE & RI \\
\hline \multicolumn{11}{|c|}{ Body weight: } \\
\hline BW4 & -0.244 & 0.40 & 0.20 & 0.389 & $\begin{array}{ll}9 & 0.70\end{array}$ & 0.8 & $32 \quad 0.63$ & 0.03 & 0.62 & \\
\hline BW6 & -0.245 & 0.05 & 0.23 & 0.362 & 20.08 & 0.81 & 0.607 & 0.03 & 0.58 & \\
\hline BW8 & -0.259 & 0.06 & 0.27 & 0.346 & $5 \quad 0.10$ & 0.84 & $4 \quad 0.605$ & 0.04 & 0.57 & \\
\hline BW10 & -0.195 & 0.06 & 0.21 & 0.235 & $5 \quad 0.11$ & 0.8 & 440.430 & 0.05 & 0.63 & \\
\hline BW12 & -0.233 & 0.06 & 0.22 & 0.265 & $\begin{array}{ll}5 & 0.12\end{array}$ & 0.8 & 0.498 & 0.06 & 0.63 & \\
\hline \multicolumn{11}{|c|}{ Growth rate: } \\
\hline RG46 & -14.64 & 4.18 & 0.27 & 17.21 & 7.51 & 0.84 & 31.89 & 3.33 & 0.57 & \\
\hline RG6-8 & -5.82 & 2.24 & 0.23 & 6.93 & 3.70 & 0.81 & 12.75 & 1.46 & 0.58 & \\
\hline RG8-10 & -4.79 & 1.97 & 0.18 & 8.82 & 3.55 & 0.84 & 13.61 & 1.58 & 0.66 & \\
\hline RG10-12 & -2.81 & 1.51 & 0.12 & 9.14 & 2.29 & 0.76 & 11.94 & 0.78 & 0.64 & \\
\hline
\end{tabular}

Minimum, maximum and ranges of predicted breeding values of growth rate were high during period 4 to 6 weeks and decreased at 6 to 8,8 to 10 and 10 to 12 weeks and their accuracies were high for all periods. Results of this study were similar to those estimates by Iraqi et al. (2002) who reported that BV for body weight at 8 and 12 weeks of age ranged from -269 to 303 and -315 to 324 grams, respectively in NZW rabbits. Hassan (2004) reported that, considering all sires, the minimum and maximum growth traits estimates of sire breeding values (SBV) at 5, 8 and 10 wks of age were not consistent among the three studied ages, which the ranges of SBV were in general higher at 5 and 10 wks than at 8 wks of age. Positive estimates of sire transmitting ability (STA) ranged from 46.2 to $61.0 \%$ for body weights at 5, 6, $8 \mathrm{wks}$ of age. These results indicated that NZW rabbits would respond to selection better at weaning ( 5 wks of age) and at $10 \mathrm{wks}$ of age than at 8 wks of age. El-Badawy, Faten (2015) reported that the predicted breeding value (PBV) of all progeny for body weight at $6,8,10$ and 12 weeks of age in NZW rabbits ranged from -330 to 120, -230 to 170, 180 to 230 and -550 to 120 grams, respectively.

The ranges of breeding values were 450, 400, 410 and 670 grams, respectively. Their accuracies increased with age. Behiry, Fatmah (2014) 
reported that breeding values, of all progeny, for body weight at 6, 8, 10 and 12 weeks of age in NZW rabbits were 200, 320, 410 and 190 grams, respectively. Accuracies minimum and maximum for boy weights were mostly higher in Baladi Red than those in NZW and crossbred rabbits.

\section{Pearson and rank correlation:}

Pearson and rank correlations were estimated among breeding values by STDFREML (Table 4). All possible Pearson and rank correlations between body weights at different ages were low or moderate, positive and significant while the correlation were negative, low and not significant correlation were observed between body weight at 4 and 6 weeks, between 6 and 8 weeks and between 10 and 12 weeks. These results reflect the common litter effect when applying the animal model to the data and the existence of the common litter effect which could have masked a part of these differences attributed to the additive gene effect, i.e. increasing nonadditive genetic effects thus additive genetic covariance became relatively smaller (El-Deighadi, 2005). This wide variation in estimates of Pearson correlations between body weights are in agreement with Iraqi, 2003; ElDeighadi, 2005 and Iraqi, 2008. Estimates of Pearson and rank correlations between most growth rates during all the periods were wide, low, moderate or high positive and significant, while the correlation were negative, low and non significant during the period from 4 to 6 weeks, these estimates fall within the range of previous estimates by Iraqi, 2003; El-Deighadi, 2005 and Iraqi, 2008.

The high estimates of Pearson correlations between body weights may be useful for selection at an early age. Hassan, 2004 reported that, across all traits, the product moment correlation coefficients among sires and dams and its rank's, according to their transmitting abilities, were highly significant and positive, except the correlation estimates between BV at 5 and 10 weeks of age. The same trend was observed in all rank correlations estimates among the ranks of the growth traits.

El-Badawy, Faten (2015) reported that using any of the correlation coefficients can do the job and they can substitute each other especially in large size population. The correlation estimates are obviously age dependent and reveal that correlated response of selection is quite feasible. Since, positive correlations of traits can suggest that these traits may be under the same gene action. 
Table 4. Person and rank correlation estimates among breeding values of body weights at $4,6,8,10$ and 12 weeks of age $(\mathrm{kg})$ in NZW rabbits.

\begin{tabular}{|c|c|c|c|c|c|}
\hline & BW4 & BW( & & BW8 & BW10 \\
\hline \multicolumn{6}{|l|}{ Person correlation: } \\
\hline BW6 & $-0.10^{* * * *}$ & & & & \\
\hline BW8 & $0.28^{* * * *}$ & $-0.001^{\mathrm{ns}}$ & & & \\
\hline BW10 & $0.07^{* * * *}$ & $0.07^{* * *}$ & $0.05^{* *}$ & & \\
\hline BW12 & $0.16^{* * * *}$ & $0.03^{\mathrm{ns}}$ & $0.28^{* * * *}$ & $-0.004^{\mathrm{ns}}$ & \\
\hline \multicolumn{6}{|l|}{ Rank correlation } \\
\hline BW6 & $-0.08^{* * * *}$ & & & & \\
\hline BW8 & $0.30^{* * * *}$ & $-0.03^{\mathrm{ns}}$ & & & \\
\hline BW10 & $0.03^{\mathrm{ns}}$ & $0.06^{* * * *}$ & $0.02^{\mathrm{ns}}$ & & \\
\hline BW12 & $0.21^{* * * *}$ & $-0.01^{\mathrm{ns}}$ & $0.27^{* * * *}$ & $-0.001^{\mathrm{ns}}$ & \\
\hline
\end{tabular}

Table Cont 4. Person and rank correlation estimates among breeding values of growth rate during the period of 4-6, 6-8, 8-10 and 10-12 weeks of age $(\%)$ in NZW rabbits.

\begin{tabular}{|lcll||}
\hline \multicolumn{1}{|l}{} & RG4-6 & RG6-8 & RG8-10 \\
\hline Person correlation: & & & \\
RG6-8 & & & \\
RG8-10 & $-0.004^{\mathrm{ns}}$ & & \\
RG10-12 & $0.16^{* * *}$ & $0.14^{* * *}$ & \\
Rank correlation & $0.05^{* *}$ & $0.29^{* * *}$ & $0.34^{* * *}$ \\
RG6-8 & & & \\
RG8-10 & $-0.007^{\mathrm{ns}}$ & & \\
RG10-12 & $0.14^{* * *}$ & $0.12^{* * *}$ & \\
& $0.005^{\mathrm{ns}}$ & $0.25^{* * *}$ & $0.36^{* * *}$ \\
\hline
\end{tabular}

$\mathrm{P} \leq .0 .01=* * ; \mathrm{P} \leq .0 .001=* * * ; \mathrm{ns}=$ Not significant.

Conclusively, The estimates of heritabilities were moderate for body weight; selection at these ages may be a useful method for improving rabbit growth. The common litter effect is very important for post-weaning growth 
GENETIC ASPECTS OFPOST-WEANING FOR GROWTHTRAITS INRABBITS 517

traits; one can conclude that the common litter effect should be included in the genetic evaluation of breeding programs. The correlation estimates are obviously age dependent and reveal that correlated response of selection is quite feasible.

\section{REFERENCES}

Abou-Khadiga. S. (2004). performance of the spanish synthetic line (V) and the local Baladi Black rabbits and their crosses under Egyptian conditions. M. Sc. Thesis, Faculty of Agriculture, Kafr El-Sheikh, Tanta University, Egypt.

Afifi, E.A. and Farid, A. (2001). Sire variance component and non-genetic factors affecting weaning weight and post-weaning growth traits in Bauscat and Baladi Red rabbits. The $2^{\text {nd }}$ inter. Conf. On Anim. prod. \& Health in Semi-Arid Areas. 4-6 Sept. 2001, El-Arish, North Sinai, Egypt, 409-420.

Behiry, F. Fatamh (2014). Genetic study for somebody measurements and its relationship with some productive traits in rabbits. $\mathrm{Ph}$. D. Thesis, Fac. Agric., Tanta Univ., Egypt.

Bhasin V, Sawal RK, Bhatia DR (1996). Genetic and nonge netic factors affecting preweaning growth in broiler rabbits. Journal Animal Sciences 11,(1); 257-61. Bokade SP, Gore AK, Kothekar MD, Deshmukh S (1993). Diallel analysis of three month body weight in rabbit. J. Vet. Anim. Sci., 24: 129-132.

Boldman K G, Kriese L A, Van Vleck L D, Van Tassell C P and Kachman S D (1995). A manual for use of MTDFREML. A set of programs to obtain estimates of variances and covariances [DRAFT]. U.S. Department of Agriculture, Agricultural Research Service, USA.

El-Badawy, E. A. Faten(2015). Improving quantitative traits in local rabbits. Ph. D. Thesis, Fac. Agric., Cairo Univ. Egypt.

El-Deighadi, A. (2005). Genetic evaluation for some productive traits in rabbits. Ph.D. Thesis, Fac. Agric., Moshtohor, Zagazig Univ., Banha Branch, Egypt.

Estany J., Camacho J., Baselga M and Blasco A. (1992). Selection response of growth rate in rabbits for meat production. Genetic, Selection, Evolution 24:527-53.

Falconer, D. S. (1981). Introduction To Quantitative Genetics. 2nd edition. London and New York, Longman. 
Ferraz J., B., S. and Eler J. P. (1994).Use of different animal models in prediction of genetic parameters of 23 traits of Californian and New Zealand White rabbits raised in Tropics and suggestion of selection criteria. ${ }_{\text {th }}$ World Rabbit Congress on Genetics Applied to Livestock Production, Canada, 08/94, Proceedings, 348-350.

Ferraz J B S and Eler J P 1996 Comparison of animal models for estimation of (co)variance components and genetic parameters of reproductive, growth and sluaughter traits of Californian and New Zealand rabbits raised under tropical conditions. $6^{\text {th }}$ World Rabbit Congress. Toulouse, Volume 2: 279-284

Ferraz J., B.,S., Johnson R., K., and Van Vleck L., D. (1992). Estimation of genetic trends and genetic parameters for reproductive and growth traits of rabbits raised in subtropics with animal models. Journal of Applied Rabbit Research, 15: 131-142

George A and Ng E (1984). A new release of SPARSPAK: The waterloo sparse matrix package. Mimeo, Department of Computer Science, University of Waterloo, Waterloo, Ontario, Canada (Agricultural Research Service, USA, 1995).

Gómez E. A., Rafel O. and Ramón J.( 2000). Preliminary genetic analysis of Caldes line: a selection experiment for a global objective. In 7th World Rabbit Congress 4-7 July 2000, Valencia Spain. World Rabbit Science Association 8 supplement, 1:417-424

Hassan, N. S. H. (2004). New Zealand White rabbits BLUP for post-weaning individual body weight under Egyptian conditions. $8^{\text {th }}$ World Rabbit Congress - September 7-10, 2004 - Puebla, Mexico

Hendrson, C. R. (1973). Sire evaluation and genetic trend. In: Proc. Anita and Gent. SYMP. In Honor of J. I. Lush. pp 10: 41.Amer. Soe. Anim. Sci., Champaign, II.

Iraqi M. M. (2003). Estimation and evaluation of genetic parameters for body weight traits of New Zealand White rabbits in Egypt using different multivariate animal models. Livestock Research for Rural Development , 15 (6) 2003.

Iraqi M. M. (2008). Estimation of Genetic parameters for post-weaning growth traits of Gabali rabbits in Egypt. Livestock Research for Rural Development, 20 (5): 
GENETIC ASPECTS OFPOST-WEANING FOR GROWTH TRAITS IN RABBITS 519

Iraqi M M, Youssef Y M K, El-Raffa A M and Khalil M H, (2002) Genetic and environmental trends for post-weaning body weights in New Zealand White and Z-line rabbits using the animal model approach. The $3^{\text {rd }}$ Scientific Conf. on Rabbit Production in Hot Climates, 8-11 October, 2002, Hurghada, Egypt.

Khalil, M.H. and Afifi, E.A. (2000). Heterosis, maternal and direct additive effects for litter performance and post-weaning growth in Gabli rabbits and their crosses with New Zealand White. $7^{\text {th }}$ World Rrabbit Con., 4-7 July 2000, Valencia Spain.

Khalil. H.H.; Afifi, E.A., and Owen, J.B. (1987). A genetic analysis of body weight traits in young Bauscat and Giza White rabbits. Anim. Prod., 45; 135-144.

Khalil M H, Ibrahim M K, Youssef Y M K and El-Deighadi A S (2000). Estimation of sire transmitting abilities for post-weaning growth traits in New Zealand White and Californian rabbits raised in adverse hot climatic Egyptian conditions using an animal model. Egyptian Poultry Science, 20(1): 65-90

Lasley JF (1978). Genetics of livestock improvement. Prentice Hall Inc., Eaglewood Clifs N.F.073, 492pp

Lukefahr S D, Odi H B and Atakora J K A 1996 Mass selection for 70-day body weight in rabbits. Journal of Animal Science, 74:1481-1489.

McReynolds WE (1974). Genetic parameters of early growth in a population of New Zealand White rabbits. Dissertation Abstract International, B35, (8): 3970.

Mrode, R. A. (1996). Linear models for the prediction of animal breeding values CAB international, Biddles Lid, Guildford, UK.

Nowier, A. E., (2012). Using of different genetic techniques to improve some economic traits in

SAS., (2003). SAS OnlineDoc 9.13 SAS Institute Inc.,Cary, NC, USA.

Youssef, Y.M.K. (2004). Heritabilities and common litter effects estimated by animal model for post-weaning growth traits in New Zealand White and Baladi Red rabbits. Egypt. Poultry. Sci., Vol. 24(1): 205-216.

Youssef, M. K.; Baslga, M.; Khalil, M. H.; Omara, M. E. and Garcia, M. L. (2008). Crossbreeding effects for post-weaning growth traits in a project of Spanish V- line with Baladi Red Rabbits in Egypt. Livestock Science (2008), doi:10.1016/j.livsci. 2008.09.014, 120: Official Journal of European Association of Animal Production. 
Youssef, M. K.; Farid, A.;Gad-Alla, S. A. and Abo-Warda, M. A. (2009). Genetic evaluation for post weaning body weight traits in three genetic groups of rabbits under Egyptian conditions. $5^{\text {th }}$ International Poultry Conference 10-13 March 2009. Taba Egypt.

\title{
النواحى الوراثية لصفات النمو فى أرانب النيوزيلتدى الأبيض.
}

\author{
أميرة سليمان الدغيدى - محمد خيرى إبراهيم.

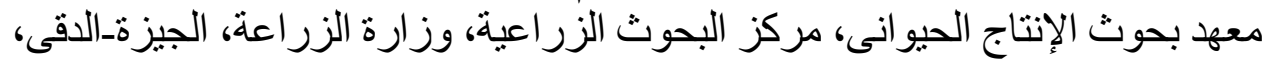

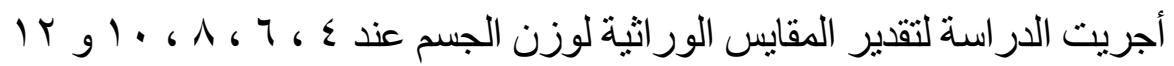

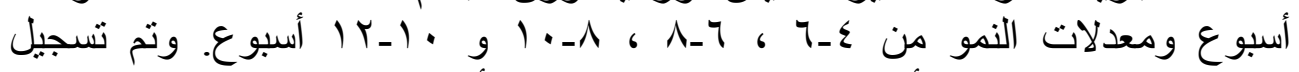

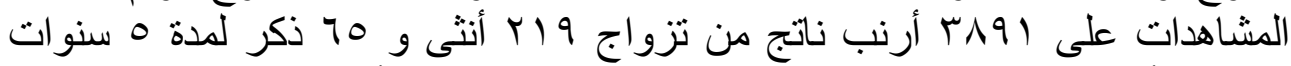
متتالية. بأستخدام برنامج النموذج الحيوانى بطريقة معظمة الأحتمال غير المقئ المقيدة وغير

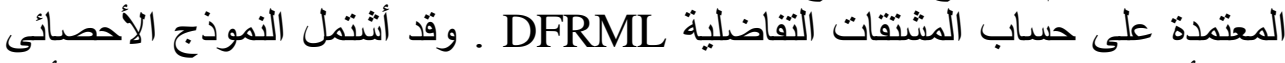

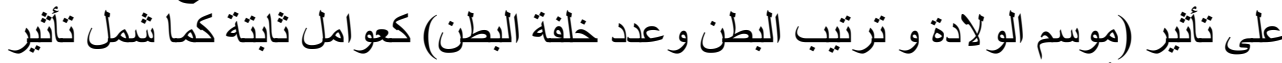
الحيو ان و التأثير البيئى الدائم كعو امل عشو لادئ ائية.

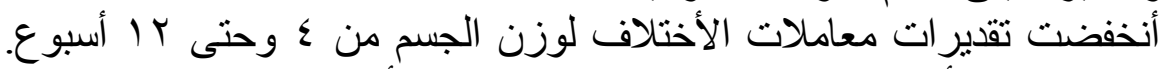

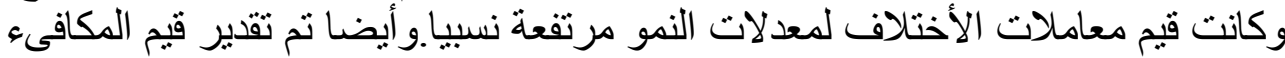

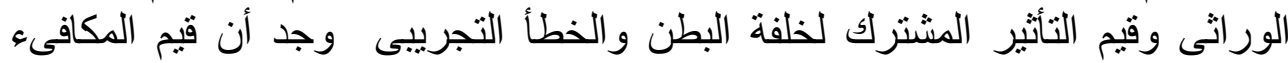

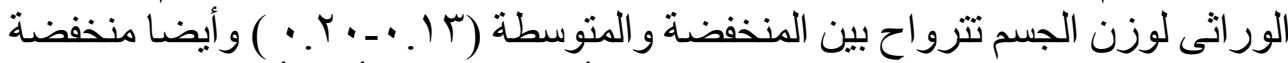

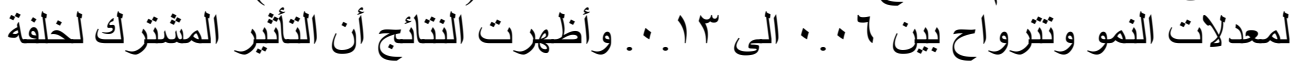

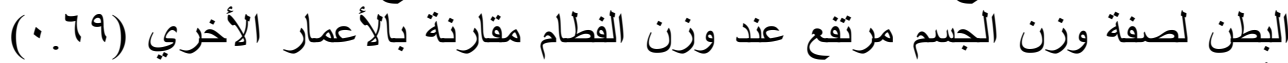

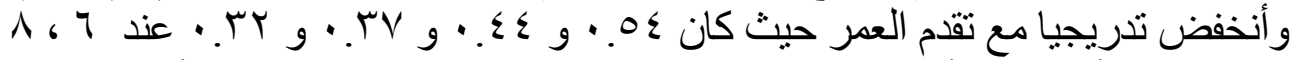

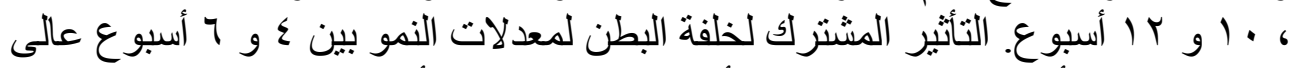

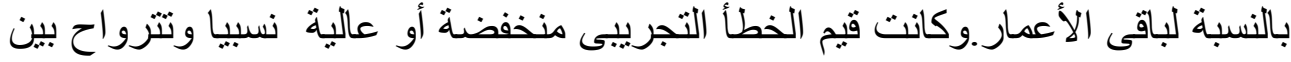

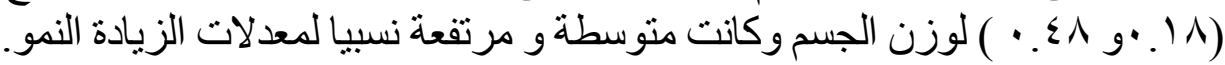

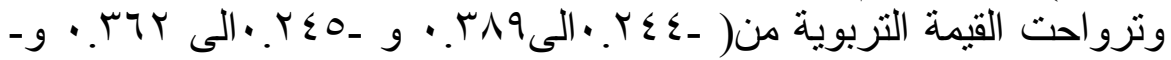

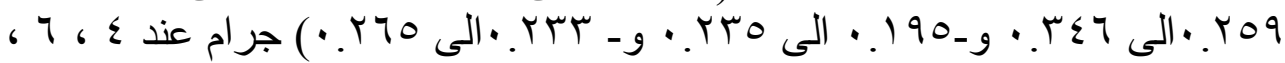


GENETIC ASPECTS OFPOST-WEANING FOR GROWTH TRAITS IN RABBITS 521

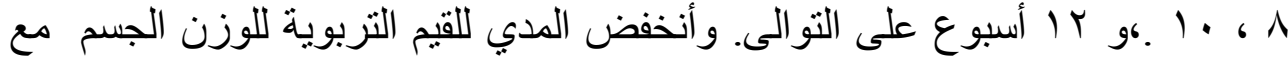

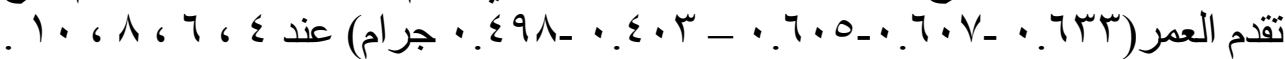

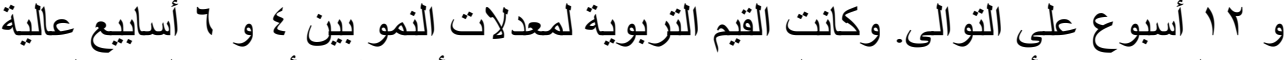

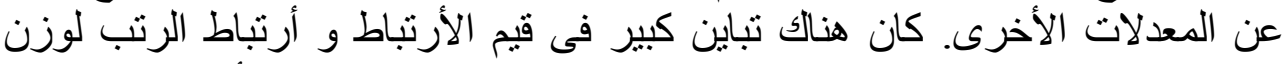

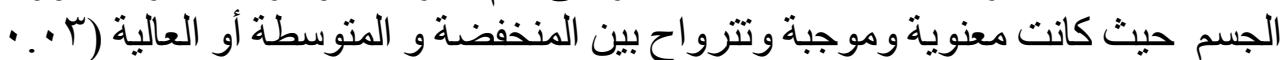

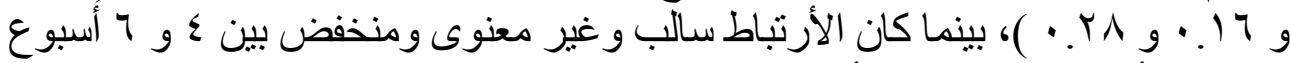

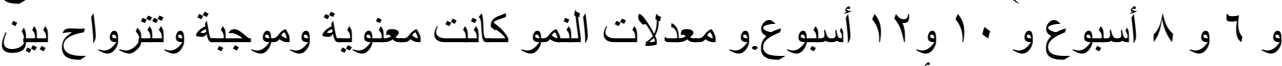

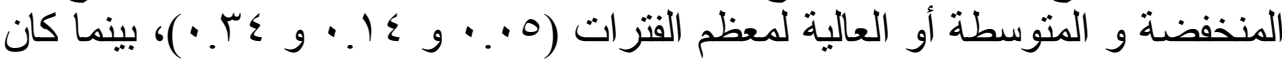

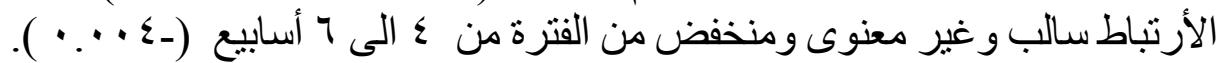

